\begin{tabular}{|l|l|l|}
\hline \multicolumn{2}{|c|}{ PublisherInfo } \\
\hline \hline PublisherName & $:$ & BioMed Central \\
\hline \hline PublisherLocation & $:$ & London \\
\hline \hline PublisherImprintName & $:$ & BioMed Central \\
\hline \hline
\end{tabular}

\title{
Calcium dependent gene regulation
}

\begin{tabular}{|l|l|l||}
\hline \multicolumn{2}{|c|}{ ArticleInfo } \\
\hline \hline ArticleID & $:$ & 4044 \\
\hline \hline ArticleDOI & $:$ & $10.1186 /$ gb-spotlight-20010409-01 \\
\hline \hline ArticleCitationID & $:$ & spotlight-20010409-01 \\
\hline \hline ArticleSequenceNumber & $:$ & 115 \\
\hline \hline ArticleCategory & $:$ & Research news \\
\hline \hline ArticleFirstPage & $:$ & 1 \\
\hline \hline ArticleLastPage & $:$ & 2 \\
\hline \hline & & RegistrationDate : 2001-04-09 \\
ArticleHistory & $:$ & OnlineDate \\
\hline \hline ArticleCopyright & $:$ & BioMed Central Ltd2001-04-09 \\
\hline \hline ArticleGrants & $:$ & \\
\hline \hline ArticleContext & $:$ & 130592211 \\
\hline \hline
\end{tabular}




\section{Tudor Toma}

Email: ttoma@mail.dntis.ro

Calcium plays an essential role in lymphocyte activation and maturation but the exact effect on gene expression is not known. In the April issue of Nature Immunology, Stefan Feske and colleagues from Harvard Medical School present evidence that $\mathrm{Ca} 2+$-dependent signalling pathways mediate both gene induction and gene repression in activated $\mathrm{T}$ cells.

In the absence of specific inhibitors, they looked at cell lines from two severe-combined immunodeficiency (SCID) patients that are characterized by a strong defect in transmembrane calcium influx. DNA microarray analysis of calcium entry-deficient and control $\mathrm{T}$ cells showed that $\mathrm{Ca} 2+$ signals both activate and repress gene expression and are largely transduced through the phosphatase calcineurin (Nat Immunol 2001, 2:316-324).

These findings add to the complexity of the gene expression machinery during $\mathrm{T}$ cell activation and may lead to the discovery of new therapeutic targets for patients with immunodeficiency syndromes.

\section{References}

1. Feske S, Giltnane J, Dolmetsch R, Staudt LM, Rao A: Gene regulation mediated by calcium signals in T lymphocytes. Nat Immunol 2001, 2:316-324., [http://www.nature.com/ni]

2. Harvard Medical School, [http://www.hms.harvard.edu/] 